\title{
Synthesis, Characterization and Antimicrobial Screening of Fe(II)-Glycine Schiff Base
}

\author{
MADHUKAR P. SHINDE ${ }^{1}$, RAGHUNATH B. TOCHE ${ }^{1,2^{*}}$, \\ SATISH M. CHAVAN ${ }^{1,3}$ and PAWAN J. TAMBDE ${ }^{4}$ \\ ${ }^{1}$ Organic Chemistry Research Centre, Department of Chemistry, \\ K.R.T. Arts, B.H. Commerce and A. M. Science College, \\ Shivajinagar, Gangapur Road, Nashik- 422 002, (MS), India \\ ${ }^{2}$ Dang Seva Mandal's Dadasaheb Bidkar College, Peth, Dist. Nashik, India \\ ${ }^{3}$ Department of Chemistry, R.N.C. Arts, J.D.B. Commerce and N.S.C. Science College, \\ Nashik- Road, Nashik- 422 101, (MS), India \\ ${ }^{4}$ Arts, Commerce and Science College, Nandgaon, Dist. Nashik, (MS), India \\ raghunath_toche@rediffmail.com
}

Received 27 July 2017 / Accepted 14 August 2017

\begin{abstract}
Fe}(\mathrm{II})$ complex of (E)-2-((2-hydroxynaphthalene-1-yl)methyleneamino)acetic acid was synthesized by reacting $\mathrm{Fe}(\mathrm{OAc})_{2}$ with Schiff base ligand in stoichiometric 1:1 ratio and was characterized by elemental analysis, IR, Mass and conductance measurement. Furthermore, this complex was screened for antimicrobial activity against E. coli, S. aureus, A. niger and C. albicans.
\end{abstract}

Keywords: 2-Hydroxy-1-naphthaldehyde, Glycine, Schiff Base, Fe(II) complex, Antimicrobial activity

\section{Introduction}

In 1864, German chemist Hugo Schiff developed a new class of organic compounds ${ }^{1}$. The active and well-designed Schiff base ligands are considered as "Privileged Ligands" by Cozzi $^{2}$. Schiff base ligands were synthesized by condensation of $\alpha$-amino acid with aldehyde to form azomethine $(-\mathrm{RC}=\mathrm{N}-)$ linkage. The metal complexes with Schiff bases play important role in biology $y^{3,4}$, analytical chemistry ${ }^{5,6}$ and industry ${ }^{7,8}$. The complexes of amino acid Schiff bases prepared from $o$-hydroxy aryl aldehydes were used as radiotracers in nuclear medicine, antibacterial and anticancer agents s,-11 $^{4}$. Bioinorganic chemistry is important and has great impact in coordination chemistry ${ }^{12}$. Haemoglobin is $\mathrm{Fe}$ (II) containing complex acts as a oxygen carrier. $\mathrm{Ca}(\mathrm{II})$ complexes is basic constituents of bone, $\mathrm{Zn}^{2+}$ ions found in three-dimensional structural framework of proteins are good examples of metal complexes in biological systems ${ }^{13}$. Metal ions act as redox transfer and hence metal complexes showed medicinal applications like organic compounds which could be used in drug discovery efforts ${ }^{14}$. They were used as therapeutic agents since $3500 \mathrm{BC}^{15}$. Over the past 
several decades, $\mathrm{Sb}$ (III) complexes were used for treatment of leishmaniasis. $\mathrm{Pt}(\mathrm{II})$ complexes are the important constituent of anti-tumour drug cisplatin ${ }^{16} . \mathrm{Ag}(\mathrm{I})$ complexes commonly used as anti-microbial agents, $\mathrm{Bi}(\mathrm{III})$ complexes for anti-ulcer treatments, $\mathrm{Au}(\mathrm{I})$ complexes as antiarthritic agents, $\mathrm{Gd}(\mathrm{III}), \mathrm{Mn}(\mathrm{II})$ and $\mathrm{Fe}(\mathrm{III})$ complexes as magnetic resonance imaging (MRI) contrast agents, $\mathrm{Sc}(\mathrm{I})$ and $\mathrm{Tc}(\mathrm{III})$ as radiopharmaceutical agents ${ }^{17}$. Hodnett and Willie ${ }^{18}$ prepared Schiff base complexes of cobalt such as trans-dichlorotetrapyridinocobalt(II) and fluropentamine cobalt(III) nitrate which showed antitumor activity. Complexes prepared from Schiff bases and metals such as cobalt, nickel, copper etc. play role in the metabolic processes in body. Musavi et al. ${ }^{19}$ synthesized various Schiff base of $N, N$ '- bis(4-fluorobenzaldehydene) with 1,2-diaminoethane. Later on they have synthesized complexes of this Schiff bases with various metal salts such as $\mathrm{MLX}_{2}$ (where, $\mathrm{M}=\mathrm{Zn}(\mathrm{II}), \mathrm{Cd}(\mathrm{II}), \mathrm{Hg}(\mathrm{II})$ and $\mathrm{X}=$ chloride, bromide, iodide, thiocyanate and azide etc.). Mohammed and co-workers ${ }^{20}$ synthesized Schiff bases by condensation of acrolein with 2-aminophenol, 2-aminophenol and phenylenediammine with cinnamaldehyde and used as inhibitors for corrosion of carbon steel in acidic media $0.5 \mathrm{~N}$ $\mathrm{HCl}$. Aliyu et $a .^{21}$ has prepared Schiff base metal complexes showed higher antibacterial activity than ligand. Asadi et $a .^{22}$ derived Schiff base from benzoyl chloride and potassium thiocynate in acetone. Then benzoyl isothiocyanate was condensed with diethylamine to form Schiff base which on condensation with metallic salts form metal complexes. These complexes conductivity and found maximum value $1.23 \times 10^{-4} \mathrm{ohm}^{-1} \mathrm{~cm}^{-1}$ after doping $\mathrm{I}_{2}$. Vergheese and Nair $^{23}$ synthesized Schiff base of 2-hydroxybenzilidene and 3-aminophenol and studied antimicrobial activity of synthesized complexes. Sharif et al. ${ }^{24}$ prepared many Schiff bases by condensation reaction of certain aromatic amines with aromatic aldehyde derivatives and determined the fluorescence properties of these Schiff bases in acidic and basic media.

In this paper we have focused on the synthesis and characterization of Schiff base complexes derived from (E)-2-((2-hydroxynapthalene-1-yl)methyleneamino)acetic acid and their antimicrobial activities. Bidentate Schiff bases obtained from glycine and 2-hydroxy-1naphthaldehyde has been used to obtain Fe(II) and Pd(II) complexes. The metal complexes obtained were well characterized by via IR, Mass, elemental analysis and conductivity measurement.

\section{Experimental}

2-Hydroxy-1- napthaldehyde (1.72 g, $0.01 \mathrm{~mol})$ was dissolved in $50 \mathrm{~mL}$ ethanol and stirred at room temperature for 5 minutes. Then it was added to stirring solution of glycine $(0.0751 \mathrm{~g}$, $0.01 \mathrm{~mol}, 25 \mathrm{~mL})$ containing $(0.56 \mathrm{~g}, 0.01 \mathrm{~mol}) \mathrm{KOH}$. The reaction mixture was refluxed for about $3 \mathrm{~h}$ (Scheme 1). A yellow grain mass separated, filtered, washed with anhydrous ethanol. It was recrystallized with methanol and then dried in vacuum over fused $\mathrm{CaCl}_{2}$. The structure of ligand was determined on the basis of spectral and analytical data and compared to literature values ${ }^{29}$. Yield $88 \%$; m.p. $240{ }^{\circ} \mathrm{C}$.

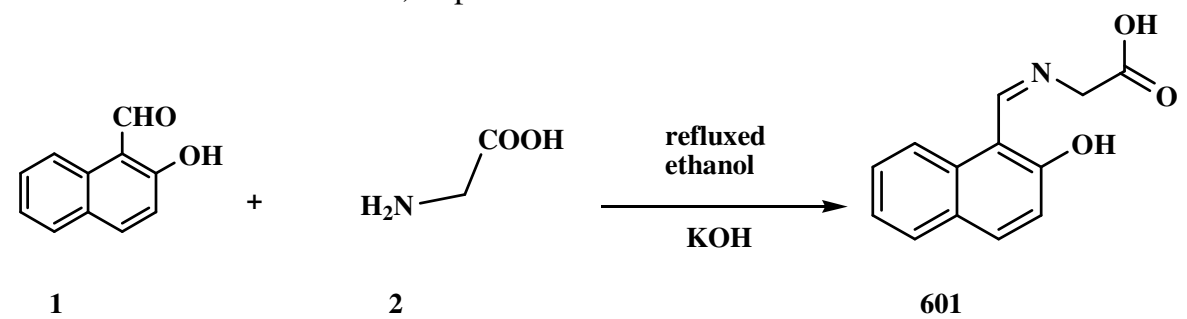

Scheme 1. Synthesis of 2-hydroxy-1-napthaldehyde based Schiff base 
Synthesis of complex $\mathrm{C}_{26} \mathrm{H}_{20} \mathrm{Fe}\left(\mathrm{NO}_{3}\right)_{2}$

Iron acetate $(0.01 \mathrm{~mol})$ in anhydrous ethanol $(15 \mathrm{~mL})$ was added in stirring solution of solution of Schiff base $(0.01 \mathrm{~mol})$ in $15 \mathrm{~mL}$ anhydrous ethanol. The resulting solution was stirred overnight at $70{ }^{\circ} \mathrm{C}$ (Scheme 2). The dark brown precipitate obtained was filtered, washed with ethanol and then with diethyl ether and dried in air

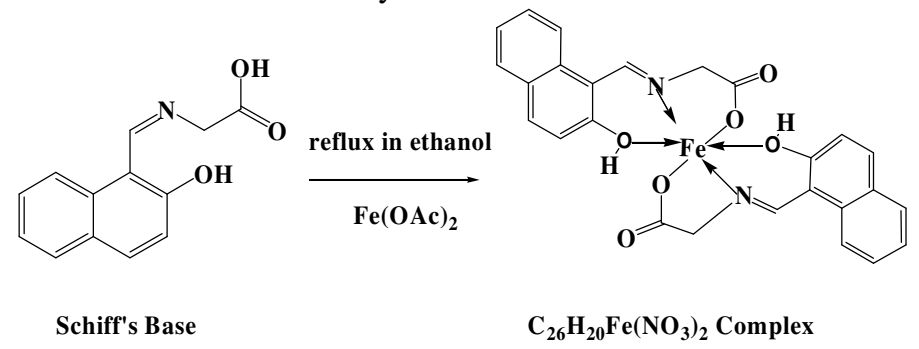

Scheme 2. Complex Formation Reaction of Schiff's base with transition metal

Spectral data for complex $\left(\mathrm{C}_{26} \mathrm{H}_{20} \mathrm{Fe}\left(\mathrm{NO}_{3}\right)_{2}\right)$

$\operatorname{IR}(\mathrm{KBr}) v \mathrm{~cm}^{-1}: 1610(\mathrm{C}=\mathrm{N}), 1367\left(\mathrm{COO}^{-}\right), 561(\mathrm{M}-\mathrm{N}), 488(\mathrm{M}-\mathrm{O}) \mathrm{MS}(\mathrm{m} / \mathrm{z}): 512$ Anal. Calcd. for C-60.96, H-3.94, N- 5.47, Fe-10.90, found C- 63.60, N-4.30, Fe- 10.77

\section{Materials and Methods}

All reagents and solvents used were of analytical grade and were used without further purification. 2-Hydroxy-1-naphthaldehyde, glycine, iron acetate was purchased from Sigma Aldrich, Merck and Spectrochem chemicals. Melting points were determined on a Gallenkamp melting point apparatus (Table 1). The ${ }^{1} \mathrm{H}$ NMR and ${ }^{13} \mathrm{C}$ NMR spectra were recorded on a Bruker Avance II $500 \mathrm{MHz}$ Spectrometer. Chemical shifts were reported in ppm relative to tetramethylsilane (TMS), and multiplicities are given as s(singlet), bs(broad singlet), d(doublet), $\mathrm{t}$ (triplet), q(quartet), or $\mathrm{m}$ (multiplet). Infrared spectra were recorded as $\mathrm{KBr}$ pellets on a Shimadzu FTIR-408 spectrophotometer. EDS analysis was performed at CIF, SPPU, Pune-7. Mass spectra were recorded on a Shimadzu LC-MS:EI QP 2010A mass spectrometer with an ionization potential of $70 \mathrm{eV}$. Molar conductivity of complexes was recorded using $1 \times 10^{-3} \mathrm{M}$ solutions in DMSO on Toshniwal TSM 15 conductivity meter. Reactions were monitored by thin layer chromatography (TLC), carried out on $0.2 \mathrm{~mm}$ silica gel $60 \mathrm{~F}_{254}$ Merck plates using UV light (254 and $366 \mathrm{~nm}$ ) for detection.

\section{Results and Discussion}

\section{Molar conductance measurements}

The value of molar conductance of complex $\mathrm{C}_{26} \mathrm{H}_{20} \mathrm{Fe}\left(\mathrm{NO}_{3}\right)_{2}$ when dissolved in DMSO was observed $15.65 \Omega^{-1} \mathrm{~cm}^{2} \mathrm{~mol}^{-1}$ respectively indicated the non-electrolytic nature of this complex.

Table 1. Reaction time, $\%$ yield, color and melting point of ligand and complex

\begin{tabular}{cccccc}
\hline Mol. formula & Ligand/Complex & Reaction time, h & Yield, \% & Colour & M.P. ${ }^{\circ} \mathrm{C}$ \\
\hline $\mathrm{C}_{13} \mathrm{H}_{11} \mathrm{NO}_{3}$ & Ligand & 4 & 88 & Yellow & 240 \\
$\mathrm{C}_{26} \mathrm{H}_{20} \mathrm{Fe}\left(\mathrm{NO}_{3}\right)_{2}$ & Complex & 12 & 80 & Brown & 242 \\
\hline
\end{tabular}

\section{IR Spectra}

IR Spectra of ligand (Figure 1) showed band at $1641 \mathrm{~cm}^{-1}$ which is due to $(\mathrm{vC}=\mathrm{N})$ confirming the formation of Schiff base. The band of $(\mathrm{vC}=\mathrm{N})$ at $1641 \mathrm{~cm}^{-1}$ in ligand was shifted to $1610 \mathrm{~cm}^{-1}$ in complex which indicate the coordination of azomethine group through its nitrogen atom ${ }^{25}$. 
The band at 1604 and $1394 \mathrm{~cm}^{-1}$ in spectrum showed the presence of $\mathrm{COO}^{-}$, these bands were shifted to $1427,1367 \mathrm{~cm}^{-1}$ in $\mathrm{Fe}(\mathrm{II})$ complex indicated metal-oxygen coordination. In complex the difference $[\Delta v(\mathrm{COO})]$ between $v_{\text {assy }}(\mathrm{COO})$ and $v_{\text {sy }}(\mathrm{COO})>200 \mathrm{~cm}^{-1}$ indicated the unidentate coordination of $\mathrm{COO}^{-}$with $\mathrm{Fe}$ (II) metal ${ }^{26}$. The band at $561 \mathrm{~cm}^{-1}$ indicated the coordination of azomethine through nitrogen with metal ion, while band at $488 \mathrm{~cm}^{-1}$ was due to (M-O) stretching in the complex ${ }^{27}$. The IR band at $3414-3340 \mathrm{~cm}^{-1}$ in complex corresponded to phenolic - $\mathrm{OH}$ stretching. This stretching frequency shift indicates the coordinate bonding of $-\mathrm{OH}$ oxygen to the metal ${ }^{28}$. Thus the ligand coordinated to free metal ion through its azomethine $(-\mathrm{RC}=\mathrm{N}-)$ nitrogen and oxygen of $\left(\mathrm{COO}^{-}\right)$carboxylate and $\mathrm{O}$ of the phenolic $-\mathrm{OH}$ indicated tridentate nature of ligand.

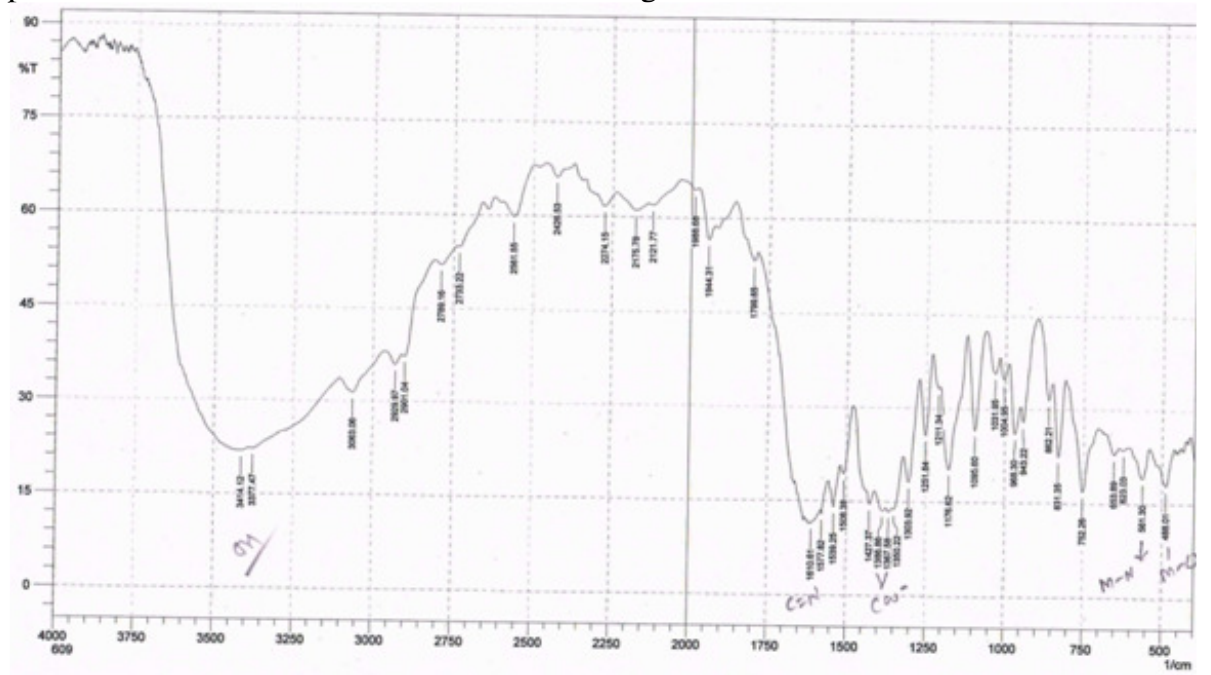

Figure 1. IR Spectra of complex, $\mathrm{C}_{26} \mathrm{H}_{20} \mathrm{Fe}\left(\mathrm{NO}_{3}\right)_{2}$

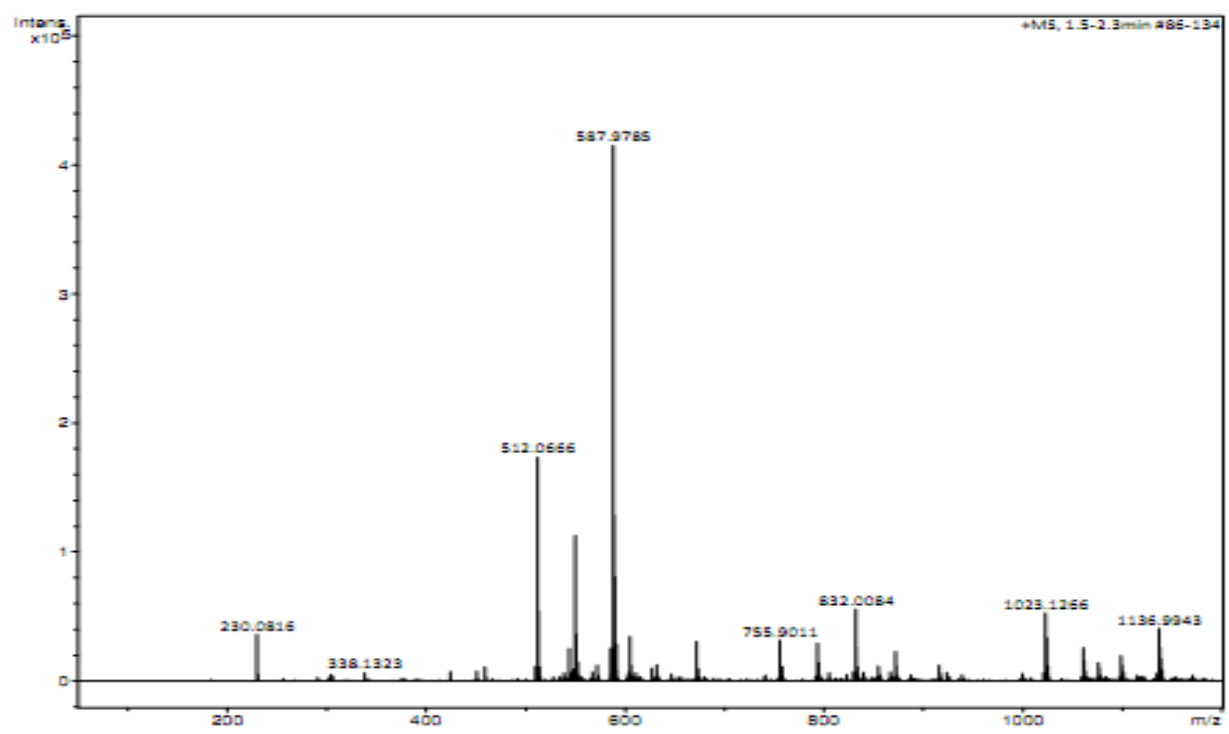

Figure 2. Mass spectrum of complex, $\mathrm{C}_{26} \mathrm{H}_{20} \mathrm{Fe}\left(\mathrm{NO}_{3}\right)_{2}$ 


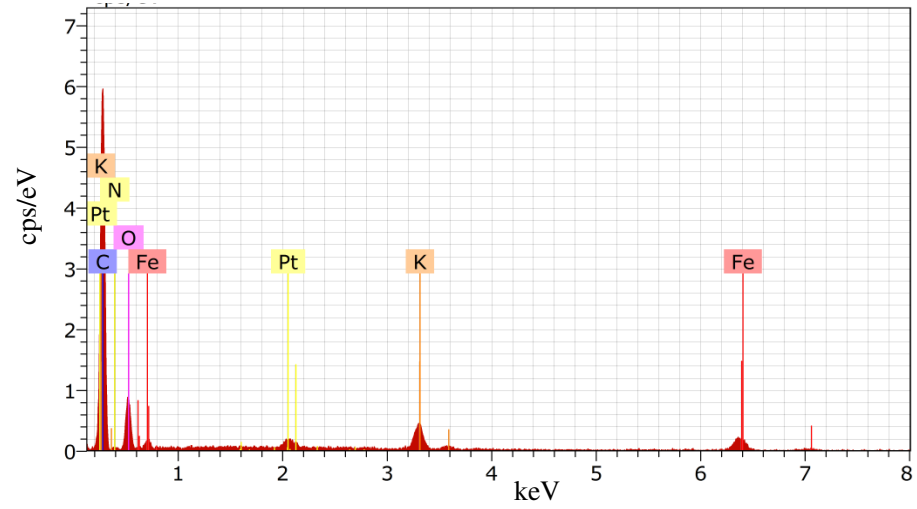

Figure 3. EDS of complex, $\mathrm{C}_{26} \mathrm{H}_{20} \mathrm{Fe}\left(\mathrm{NO}_{3}\right)_{2}$

Mass spectrum of complex

Mass spectra of complex (Figure 2) shows M+ peak at 512.06 corresponded to molecular formula $\mathrm{C}_{26} \mathrm{H}_{20} \mathrm{Fe}\left(\mathrm{NO}_{3}\right)_{2}$.

\section{EDS of complex}

EDS of complex shows $10.77 \%$ of $\mathrm{Fe}(\mathrm{II})$, which is in good agreement with elemental analysis (Figure 3).

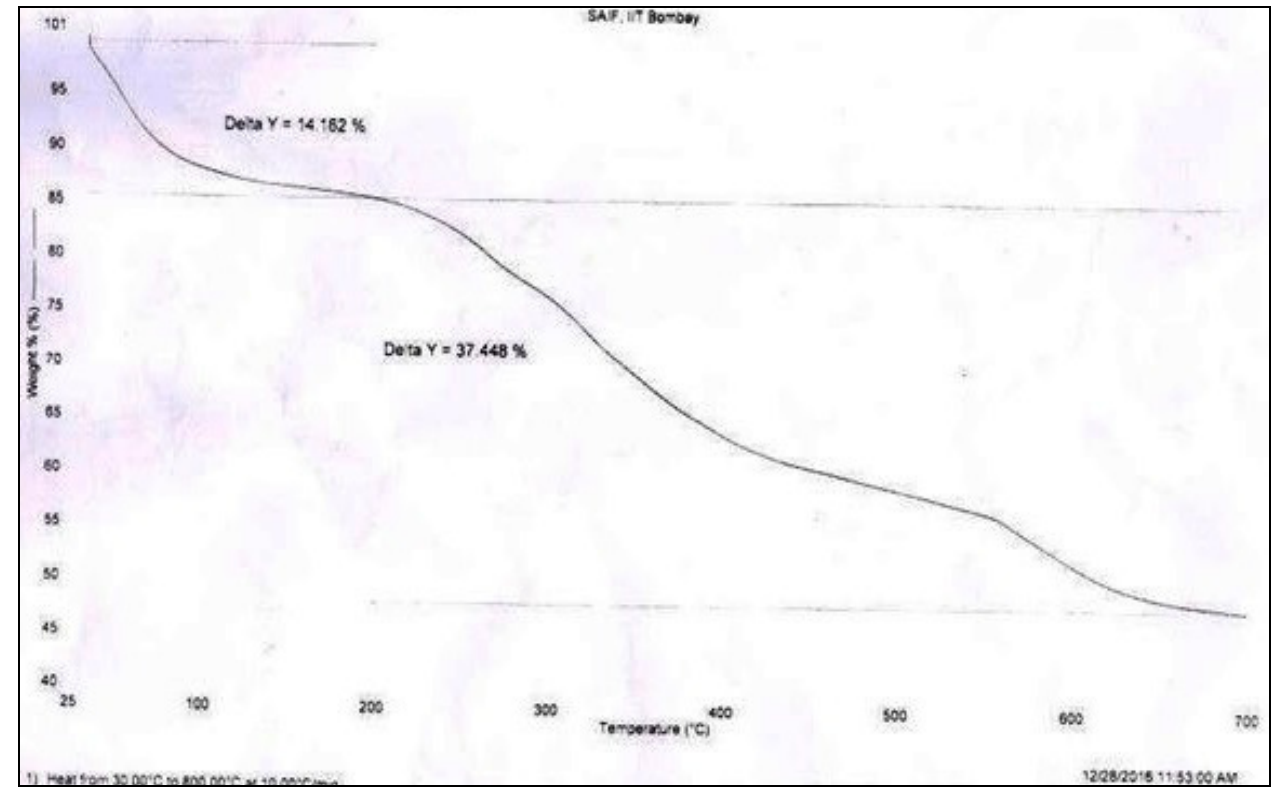

Figure 4. TGA of complex $\mathrm{C}_{26} \mathrm{H}_{20} \mathrm{Fe}\left(\mathrm{NO}_{3}\right)_{2}$

$T G A$

The TGA curve of synthesized Fe complex (Figure 4) reveals weight loss occurring in two stages. The first small weight loss is due to absorbed moisture which is found at $100{ }^{\circ} \mathrm{C}$ and the second exothermic loss of $37.448 \%$ due to decomposition of $\mathrm{Fe}$ complex and crystallization of $\mathrm{FeO}$ particles. The theoretical weight loss calculated by conversion of 
complex precursor to $\mathrm{FeO}$ is in good agreement with the measured value. The process accounts for one third of total weight loss in the whole decomposition process from 100 to $600{ }^{\circ} \mathrm{C}$ according to TGA results, with the major loss occurring between 200 to $500{ }^{\circ} \mathrm{C}$. The TGA result shows that complex is highly stable up to $225^{\circ} \mathrm{C}$.

\section{Antimicrobial assay}

The antimicrobial assay of Fe metal complex was done using agar well plate method (Figure 5). The antibacterial and antifungal assays were performed in Muller-Hinton broth and Crazek Dox broth ${ }^{30}$. The standard strains used was procured from Microbial Culture Collection, Pune, India. Antimicrobial evaluation was performed using the bacteria reseeded in Muller-Hinton broth for $24 \mathrm{~h}$ at $37{ }^{\circ} \mathrm{C}$ and fungi reseeded in Crazek Dox broth $^{30}$ for $48 \mathrm{~h}$ at $25^{\circ} \mathrm{C}$. The antibacterial activity of tested samples were studied (Table 2) in triplicate against gram positive bacteria Staphylococcus aureus (ATCC 29737) and gram negative bacteria Escherichia coli (ATCC 25922). The same samples were tested for antifungal activity in triplicate against Candida albicans (MTCC 277) and Aspergillus niger (MCIM 545). The compounds were dissolved in DMSO at desired concentrations of $40,20,10 \mu \mathrm{g} / \mathrm{mL}$. DMSO was loaded as negative control. Gentamicin $(10 \mu \mathrm{g} / \mathrm{mL})$ and Fluconazole $(20 \mu \mathrm{g} / \mathrm{mL})$ were used as standards for evaluating the antibacterial and antifungal activity. The zone of inhibition $(\mathrm{mm})$ was determined from the diameter of the zone of inhibition using caliper as per National Committee for Chemical Laboratory Standards (NCCLS, M7-A5, January 2000). Both metal complexes shows good antibacterial as well as good antifungal activity.

The complex $\mathrm{C}_{26} \mathrm{H}_{20} \mathrm{Fe}\left(\mathrm{NO}_{3}\right)_{2}$ showed excellent antibacterial activity against Escherichia coli (ATCC25922) with MIC $20 \mu \mathrm{g} / \mathrm{mL}$ when compared with standard antibacterial drug gentamicin $(10 \mu \mathrm{g} / \mathrm{mL})$. Similarly it also showed excellent anifungal activities against Aspergillus niger (MCIM 545), Candida albicans (MTCC 277) with MIC $10 \mu \mathrm{g} / \mathrm{mL}$ when compared with standard antifungal drug fluconazole $(20 \mu \mathrm{g} / \mathrm{mL})$ (Table 3).

Table 2. Antimicrobial screening of complex $\mathrm{C}_{26} \mathrm{H}_{20} \mathrm{Fe}\left(\mathrm{NO}_{3}\right)_{2}$

\begin{tabular}{ccccc}
\hline & \multicolumn{4}{c}{ Inhibition Zone Diameter, mm } \\
\cline { 2 - 5 } Complex & $\begin{array}{c}\text { E. coli } \\
\text { (ATCC25922) }\end{array}$ & $\begin{array}{c}\text { S. aureus } \\
\text { (ATCC 29737) }\end{array}$ & $\begin{array}{c}\text { A.niger } \\
\text { (MCIM 545) }\end{array}$ & $\begin{array}{c}\text { C.albicans } \\
\text { (MTCC 277) }\end{array}$ \\
\hline $\mathrm{C}_{26} \mathrm{H}_{20} \mathrm{Fe}\left(\mathrm{NO}_{3}\right)_{2}$ & $15 \pm 0.3$ & $22 \pm 0.5$ & $21 \pm 0.8$ & $19 \pm 0.8$ \\
DMSO & $11 \pm 0.7$ & $12 \pm 0.9$ & $12 \pm 0.6$ & $13 \pm 0.3$ \\
Gentamicin & $22 \pm 0.4$ & $23 \pm 0.7$ & - & - \\
Fluconazole & - & - & $23 \pm 0.8$ & $24 \pm 0.5$ \\
\hline
\end{tabular}

Gentamicin $(10 \mu \mathrm{g} / \mathrm{mL})$ and fluconazole $(20 \mu \mathrm{g} / \mathrm{mL})$ Inhibition Zone= 9-14 mm: slight activity, 15-19 mm: moderate activity, 20 -24 $\mathrm{mm}$ : high activity, >25 mm: excellent activity.

Table 3. Antimicrobial screening of complex $\mathrm{C}_{26} \mathrm{H}_{20} \mathrm{Fe}\left(\mathrm{NO}_{3}\right)_{2}$

\begin{tabular}{lcccc}
\hline \multirow{2}{*}{ Complex } & \multicolumn{4}{c}{ Minimum Inhibition Concentration (MIC), $\mu \mathrm{g} / \mathrm{mL}$} \\
\cline { 2 - 5 } & $\begin{array}{c}\text { E.coli } \\
\text { (ATCC25922) }\end{array}$ & $\begin{array}{c}\text { S.aureus } \\
\text { (ATCC 29737) }\end{array}$ & $\begin{array}{c}\text { A.Niger } \\
\text { (MCIM 545) }\end{array}$ & $\begin{array}{c}\text { C.albicans } \\
\text { (MTCC 277) }\end{array}$ \\
\hline $\mathrm{C}_{26} \mathrm{H}_{20} \mathrm{Fe}\left(\mathrm{NO}_{3}\right)_{2}$ & 10 & 10 & 10 & 10 \\
Gentamicin & 10 & 10 & - & - \\
Fluconazole & - & - & 20 & 20 \\
\hline Gentamicin $(10 \mu \mathrm{g} / \mathrm{mL})$ and Fluconazole $(20 \mu \mathrm{g} / \mathrm{mL}),($ MIC in $\mu \mathrm{g} / \mathrm{mL})=10 \mu \mathrm{g} / \mathrm{mL}:$ excellent activity, \\
$20 \mu \mathrm{g} / \mathrm{mL}:$ moderate activity, $40 \mu \mathrm{g} / \mathrm{mL}:$ slight activity
\end{tabular}




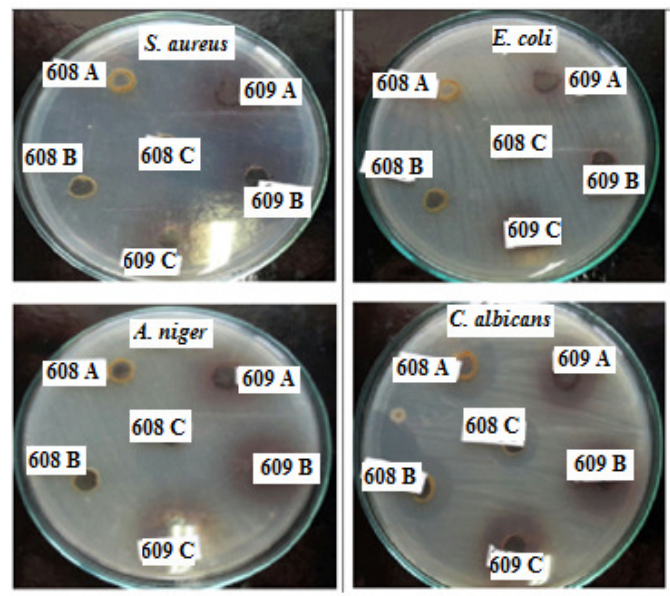

$609 \mathrm{~A}: 40 \mu \mathrm{g} / \mathrm{mL} ; 609 \mathrm{~B}: 20 \mu \mathrm{g} / \mathrm{mL} ; 609 \mathrm{C}: 10 \mu \mathrm{g} / \mathrm{mL}$

Figure 5. Antimicrobial screening of complex (609): $\mathrm{C}_{26} \mathrm{H}_{20} \mathrm{Fe}\left(\mathrm{NO}_{3}\right)_{2}$

\section{Conclusion}

The synthesis and characterization of Fe(II) Complex were studied herein in the light of elemental analysis, ${ }^{1} \mathrm{H}$ NMR, IR, electronic spectra and mass spectra. It was concluded that the Schiff base coordinating through the azomethine nitrogen and carboxylate oxygen. The synthesized complex has good antimicrobial activities.

\section{Acknowledgement}

The authors are thankful to UGC,WRO, Pune for financial support to this research project. and Savitribai Phule Pune University, Pune, SAIF, IIT Bombay, M.V.P. Samaj, Principal, K.R.T. Arts, B.H. Commerce and A. M. Science College, Shivajinagar, Gangapur Road, Nashik- 422 002, (MS), India for facilities.

\section{References}

1. Schiff H, Justus Liebigs Ann Chem., 1864, 131(1), 118-119; DOI:10.1002/jlac.18641310113

2. Cozzi. P G, Chem Soc Rev., 2004, 33, 410-421;DOI: 10.1039/B307853C

3. $\quad$ Nath M, Yadav R, Bull Chem Soc Japan, 1997, 70, 1331-1337;

DOI:10.1246/bcsj.70.1331

4. Cohan Z H, Praveen M and Ghaffar A, Synth React Inorg Met-Org Chem., 1998, 28(10), 1673-1687; DOI:10.1080/00945719809349422

5. Thankarajan N and Mohnan K, J Indian Chem Soc., 1985, LXII, 81-82.

6. El-Brosy A M and Al-Ghaman S M, Analyst, 1997, 122, 147-150; DOI:10.1039/A604847A

7. Polbom F K, Robl C and Beck W, Can J Chem., 1995, 73(7), 1164-1174; DOI:10.1139/v95-143

8. Tarafder M T H and Khan A R, J Indian Chem Soc., 1997, 74, 489-491.

9. Du Preez JG H, Gerber T I A, Fourie P J and VanWyk A, J Coord Chem., 1994, 13, 1473-1478.

10. Aminabhavi T M, Biradar N S, Patil S B, Roddabasanagoudar V L and Rudzinski W E, Inorg Chim Acta, 1985, 107(4), 231-324; DOI:10.1016/S0020-1693(00)82293-8 
11. Kong D, Zhang A, Zhu Q, Xie Y and Zhou X I, ZhonggoYaowuZazhi, 1998, 8(4), 245-249 (Chem Abstr.1999,130, 53640)

12. Maria Kulandai Raja Balan, Francis Nicholas Ashok R, Vasanthi M, Prabu R and Paulraj A, Int J Life Sci Pharma Res., 2013, 3(2), L-65-L-75

13. Cardillo G and Tomasini C, Chem Soc Rev., 1996, 25, 117-128; DOI:10.1039/CS9962500117

14. Juaristi E, Enantioselective Synthesis of $\beta$-Amino Acids, Wiley-VCH, New York, 1997.

15. George G I, The Organic Chemistry of $\beta$-Lactams, Wiley-VCH: New York, 1993.

16. Traxler P, Trinks U, Buchduger E, Mett H, Meyer T, Muller M, Regenass U, Rosel J, Lydon N, J Med Chem., 1995, 38(13), 2441-2448; DOI:10.1021/jm00013a020

17. Juaristi E and Lopez-Ruiz H, Curr Med Chem., 1999, 6, 983-1004.

18. Hodnett E M and Willie W, Physical Science, 107.

19. Montazerozohari M, Khani S, Joohari S and Musavi S A, J Chem.., 2012, 9(4), 24832492; DOI:10.1155/2012/952926

20. Mohammed Qasim Mohammed, J Basrah Researches (Science), 2011, 37, 4A/15, 116-130.

21. Aliyu H N and Sani U, International Res J Pharm Pharmacology, 2012, 2(2), 40.

22. Muhanned Jawad KadhimAl-Assadi, J Basrah Researches (Science), 2012, 37, 104-110.

23. Verghese S and Muraleedharan Nair M K, Res J Pharm Biol Chem Sci., 2010, 1(2), 347-353.

24. Ibrahim M N and Sharif S E A, J Chem., 2007, 4(4), 531-535; DOI:10.1155/2007/191805

25. Percy G C and Thornton D A, J Inorg Nucl Chem., 1972, 34(11), 3357-3367; DOI:10.1016/0022-1902(72)80230-6

26. Makode J T and Aswar A S, Indian J Chem., 2004, 43A(10), 2120-2125.

27. Reddy P M, Ho Y P, Shanker K, Rohini R and Ravinder V, Eur J Med Chem., 2009, 44(6), 2621-2625; DOI:10.1016/j.ejmech.2008.09.035

28. Semanthi B, Indian J Chem., 2005, 17(2), 167-175.

29. Xiu Ling Zhang and Feng Guo, Asian J Chem., 2008, 20(8), 6269-6275.

30. MounyrBalouiri, MoulaySadiki, SaadKoraichiIbnsouda, J Pharm Anal., 2016, 6(2), 71-79; DOI:10.1016/j.jpha.2015.11.005 